\title{
Respons Pertumbuhan Bibit Setek Teh (Camellia sinensis (L.) O. Kuntze) Klon GMB 7 pada Berbagai Interval Penyiraman
}

\author{
Erdiansyah Rezamela ${ }^{1 *}$, Santi Rosniawaty ${ }^{2}$, dan Cucu Suherman ${ }^{2}$ \\ ${ }^{1}$ Pusat Penelitian Teh dan Kina \\ 2 Fakultas Pertanian Universitas Padjadjaran \\ *Alamat korespondensi: rezamela.erdiansyah@gmail.com
}

\begin{abstract}
Growth response of GMB 7 clone tea cuttings under various watering interval
\end{abstract}

Drought stress on tea cuttings impact on growth declined and death of plants. This study aimed to determine the response of tea cuttings growth to drought stress and to find the optimum watering interval. The research was conducted at Research Institute for Tea and Cinchona, Gambung, West Java ( $\pm 1,350 \mathrm{~m}$ asl) from January to March 2020. GMB 7 clone tea cuttings aged 6 months were given watering treatment at $0,13,5,7$ and 9 days intervals, without watering and chitosan application as an anti-transpirant. The results obtained after $57^{\text {th }}$ day showed that the 7 -days watering interval have significant effect and the highest response to leaf area, leaf area index and shoot dry weight, but did not significantly affect on plant height and stem diameter. Watering at all different intervals and chitosan treatment showed better leaf number, root-shoot ratio and least of fallen leaf than without watering. Based on non-linear regression analysis, root-shoot ratio, shoot dry weight, number and leaf area reaching their optimum at the 6-day watering interval. Therefore, watering once every 6 days was an optimum interval to maintain growth of GMB7 clone tea cuttings in drought stress conditions during adaptation process.

Keywords: Drought stress, Watering interval, Tea cuttings

\begin{abstract}
ABSTRAK
Cekaman kekeringan pada bibit teh dapat menyebabkan pertumbuhan terhambat hingga kematian tanaman. Penelitian ini bertujuan untuk mengetahui respons pertumbuhan bibit teh terhadap cekaman kekeringan dan mencari interval penyiraman yang ideal bagi pertumbuhan bibit teh. Penelitian dilaksanakan di Pusat Penelitian Teh dan Kina, Gambung Jawa Barat berada pada ketinggian $\pm 1.350 \mathrm{~m}$ di atas permukaan laut (dpl) mulai Januari sampai Maret 2020. Bibit setek teh klon GMB 7 umur 6 bulan diberi perlakuan penyiraman dengan interval 0, 1, 3, 5, 7 dan 9 hari ditambah perlakuan tanpa penyiraman dan aplikasi kitosan sebagai anti-transpirant. Hasil yang didapat setelah hari ke-57, interval penyiraman 7 hari sekali memberikan pengaruh nyata dan respons tertinggi terhadap luas daun, indeks luas daun dan bobot kering tajuk, namun tidak berpengaruh nyata terhadap tinggi tanaman dan diameter batang. Penyiraman pada semua interval yang berbeda dan perlakuan kitosan menunjukkan nilai jumlah daun, root shoot ratio dan pengurangan daun yang lebih tinggi dibanding tanpa penyiraman. Berdasarkan analisis regresi non linear, kecenderungan penurunan root shoot ratio, bobot kering tajuk, jumlah dan luas daun mulai terjadi setelah mencapai titik optimumnya pada interval penyiraman 6 hari sekali. Oleh karena itu, penyiraman 6 hari sekali merupakan interval ideal untuk mempertahankan pertumbuhan bibit teh klon GMB7 pada kondisi cekaman kekeringan saat proses adaptasi.
\end{abstract}

Kata kunci: Cekaman kekeringan, Interval penyiraman, Bibit setek teh 


\section{PENDAHULUAN}

Selama tahun 2014 sampai 2018, luas tanaman teh di Indonesia menurun sebesar $0,75 \%$ per tahun diikuti penurunan produksi sebesar $3,80 \%$ per tahun dan penurunan produktivitas sebesar $1,14 \%$ per tahun (ITC, 2019; BPS, 2018). Upaya yang perlu dilakukan sebagai langkah peningkatan produktivitas tanaman di antaranya percepatan peremajaan kebun-kebun teh tua melalui penanaman ulang dan pemadatan populasi tanaman (Santoso \& Suprihartini, 2006; 2007). Intensifikasi pengadaan bibit teh prima siap salur merupakan langkah awal keberhasilan program peremajaan teh tua dan pemadatan populasi. Keberhasilan pertumbuhan bahan tanam teh di persemaian merupakan syarat awal keberhasilan budidaya teh yang berkesinambungan (Choubey et al., 2013; Wulansari dkk., 2017).

Bahan tanam teh diperoleh dari perbanyakan secara vegetatif menggunakan setek daun tunggal (Hajra, 2001; PPTK, 2006), sehingga keberhasilan pertumbuhan vegetatif merupakan faktor utama pendukung keberhasilan bibit teh siap salur. Keberhasilan pertumbuhan bibit teh di persemaian diharapkan mencapai lebih dari $80 \%$ bibit teh siap salur, namun permasalahan yang biasa terjadi adalah rendahnya persentase bibit teh siap salur yang hanya mencapai 40\%-50\% (Wulansari dkk., 2017). Hal ini salah satunya disebabkan oleh cekaman abiotik berupa kekeringan pada pada musim kemarau saat bibit diadaptasikan umur 6 bulan di luar naungan.

Kekeringan terjadi karena ketidakseimbangan antara air yang tersedia dengan laju transpirasi, sehingga terjadi defisit air dalam tanaman, lalu sel mengalami dehidrasi, akibatnya terjadi cekaman osmotik akhirnya pada jangka panjang mengakibatkan keluarnya cairan sitoplasma ke luar sel (Maritim et al., 2015). Cekaman kekeringan akan menyebabkan penurunan kadar air tanah (Kartawijaya, 1992). Pada tanaman teh, penurunan kadar air tanah di bawah 15\% akan berdampak terhadap defisit air pada tanaman (Dalimoenthe \& Rachmiati, 2009; Maritim et al., 2015). Penurunan kadar lengas tanah mengakibatkan menurunannya kandungan air relatif dalam daun (Setiawan dkk., 2013). Kandungan air dalam daun berkorelasi negatif dengan interval penyiraman, semakin panjang interval penyiraman artinya semakin lama tanaman tidak mendapatkan pasokan air semakin rendah kandungan air dalam tanaman tersebut (Setiawan dkk., 2013).
Tanaman merespons secara fisiologis dan biokimia untuk menghadapi cekaman kekeringan dengan tujuan utama meningkatkan tekanan turgor sel (Osakabe et al., 2014; Maritim et al., 2015). Cekaman kekeringan mengakibatkan penurunan laju fotosintesis bersih yang akan mengakibatkan penghambatan pertumbuhan (Osakabe et al., 2014; Maritim et al., 2015). Dampak kekeringan secara bertahap terhadap pertumbuhan tanaman teh yang dapat dilihat dengan kasat mata bermula pada tahap layu sementara, layu permanen, didukung suhu udara dan kelembaban yang tinggi akan mengakibatkan gugur daun, kering pucuk dan ranting muda hingga mengakibatkan kematian pada tanaman (Sukasman, 1992).

Dampak negatif dari cekaman abiotik dapat dikurangi di antaranya melalui aplikasi biostimulator, salah satunya dengan kitosan (Górnik et al., 2008). Kitosan adalah senyawa organik turunan kitin yang merupakan komponen utama dari cangkang arthropoda (Malerba \& Cerana, 2016). Aplikasi kitosan melalui daun tidak hanya meningkatkan pertumbuhan tanaman (Sasmita \& Darban, 2016; Abu-Muriefah, 2013; Farouk \& Amany, 2012; Abdel-Mawgoud et al., 2010; Górnik et al., 2008) tetapi juga mengeluarkan mekanisme resistensi dalam menghadapi kekeringan (Malerba \& Cerana, 2016). Kitosan menginduksi ketahanan terhadap cekaman kekeringan diantaranya melalui mekanisme penutupan stomata, mengurangi kerusakan membran sel akibat peroksida lipid, dan menahan penurunan kandungan air nisbi pada kondisi kekeringan (Zhang et al., 2018; Pichyangkura \& Chadchawan, 2015; Yang et al., 2009). Tujuan penelitian ini adalah untuk mengetahui respons pertumbuhan bibit teh terhadap berbagai kondisi cekaman kekeringan dan menentukan interval ideal yang dapat mempertahakan pertumbuhan vegetatif di pembibitan.

\section{BAHAN DAN METODE}

Penelitian dilaksanakan di Pusat Penelitian Teh dan Kina, Bandung, Jawa Barat yang berada pada ketinggian $\pm 1.350 \mathrm{~m}$ dpl dengan ordo tanah Andisol dan tipe iklim B menurut klasifikasi Schdmit dan Ferguson (1951). Penelitian dilaksanakan pada bulan Januari sampai Maret 2020. Bahan yang digunakan dalam penelitian ini antara lain bibit setek teh klon GMB 7 umur 6 bulan yang sudah pada tahapan buka sungkup plastik dan masuk 
ke tahapan adaptasi di luar naungan. Antitranspirant yang digunakan dalam penelitian ini adalah kitosan berbentuk cairan yang merupakan hasil ekstraksi alami dari limbah arthropoda laut seperti kulit udang, cangkang kepiting, dan tulang rawan cumi-cumi

Cekaman kekeringan dikondisikan dengan interval penyiraman yang berbeda. Penelitian disusun menggunakan Rancangan Acak Kelompok Lengkap (RAKL) faktor tunggal dengan 7 perlakuan interval penyiraman diantaranya tanpa penyiraman (P0); tanpa penyiraman dikombinasikan dengan aplikasi kitosan $2 \mathrm{~mL} . \mathrm{L}^{-1}$ (P1); penyiraman interval 1 hari sekali (P2); 3 hari sekali (P3); 5 hari sekali (P4); 7 hari sekali (P5); dan 9 hari sekali (P6). Setiap perlakuan terdiri dari 4 ulangan, sehingga jumlah plot perlakuan $7 \times 4=28$ plot. Setiap plot perlakuan terdiri dari tiga bibit, sehingga terdapat 84 bibit memiliki pertumbuhan vegetatif yang seragam. Komposisi media pembibitan standar tanaman teh terdiri dari $1 / 3$ bagian atas polibag diisi top soil dan 2/3 bagian bawah polibag diisi sub soil. Bibit teh ditempatkan di dalam naungan plastik untuk melindungi bahan tanam dari bias air hujan. Tinggi kerangka naungan plastik dibuat sesuai standar tinggi naungan pembibitan yakni $2,5 \mathrm{~m}$ (PPTK, 2006). Pada semua sisi ditutup menggunakan plastik. Plastik yang digunakan berjenis polyethilen (PE) bening dengan ketebalan sesuai standar sungkup plastik pembibitan PPTK yakni $0,08 \mathrm{~mm}$ (PPTK, 2006).

Sebelum aplikasi perlakuan interval penyiraman, ditentukan terlebih dahulu volume air penyiraman. Volume air yang disiramkan diperoleh dari volume air yang dibutuhkan pada kapasitas lapang tanaman sampel yaitu volume air yang diberikan dikurangi dengan volume air yang menetes (Parwata dkk., 2010).

Metode penentuan kapasitas lapang (KL) merujuk pada Suharti dkk., (2017) disesuaikan dengan berat sampel media tanam bibit setek teh. Media disiram air sampai keadaan jenuh dan dibiarkan selama 3x24 jam sampai air tidak menetes lagi, selanjutnya media ditimbang sebagai berat basah. Media dimasukkan ke dalam oven pada suhu $100^{\circ} \mathrm{C}$ selama 24 jam, setelah itu ditimbang kembali sebagai berat kering. Penentuan kapasitas lapang (KL) dilakukan pengulangan sebanyak 3 kali (Suharti dkk., 2017).

Parameter yang diamati antara lain tinggi tanaman $(\mathrm{cm})$, jumlah daun (helai), dan diameter batang (mm) diamati setiap dua minggu.
Pertambahan jumlah daun diperoleh dari pengurangan jumlah daun pada pengamatan sebelumnya. Pengamatan analisis pertumbuhan dilakukan dengan destruksi di akhir pengamatan meliputi bobot kering tajuk dan akar (g), root shoot ratio $(R / S)$, luas daun $\left(\mathrm{cm}^{2}\right)$, indeks luas daun dan berat daun khas/ spesific leaf weight (SLW) $\left(\mathrm{g} / \mathrm{cm}^{2}\right)$. Perhitungan luas daun dilakukan dengan menggunakan aplikasi software Image J-Fiji bersamaan dengan perhitungan bobot tajuk dan akar.

Data hasil pengamatan dianalisis ragam dengan menggunakan program SPSS ver 2.2 pada tingkat kepercayaan 95\%. Uji lanjut dilakukan apabila terdapat pengaruh nyata pada perlakuan menggunakan Uji Jarak Berganda Duncan/Duncan Multiple Range Test (DMRT) pada tingkat kepercayaan 95\%. Interval penyiraman optimal didasarkan pada parameter jumlah daun, luas daun, dan root to shoot ratio yang diperoleh menggunakan analisis dilakukan analisis regresi non linear dengan persamaan:

$$
Y=\beta_{0}+\beta_{1} X+\beta_{2} X^{2}+\varepsilon
$$

dimana

$\mathrm{Y}=$ pertumbuhan daun (respon)

$\beta_{0} \quad=$ intersep

$\beta_{1,} \beta_{2}=$ koefisien regresi

$X \quad=$ interval penyiraman (prediktor)

$\varepsilon \quad=$ faktor galat

Data hasil pengamatan dianalisis ragam dengan menggunakan program SPSS ver 2.2 pada tingkat kepercayaan $95 \%$.

$$
d Y / d X=\beta_{1}+2 \beta_{2} X
$$

dimana,

$Y \quad=$ pertumbuhan daun

$\beta_{1,} \beta_{2}=$ konstanta

$X \quad=$ interval penyiraman

Untuk mengukur kekuatan dan arah hubungan linier antar variabel pengamatan digunakan analisis korelasi Pearson. Dua variabel dikatakan berkorelasi apabila perubahan salah satu variabel disertai dengan perubahan variabel lainnya, baik dalam arah yang sama ataupun arah yang sebaliknya. Koefisien determinasi (r) korelasi Pearson disusun dalam rumus:

$$
r=\frac{\sum x y-\frac{\left(\sum x\right)\left(\sum y\right)}{n}}{\sqrt{\left(\sum x^{2}-\frac{\left(\sum x\right)^{2}}{n}\right)\left(\sum y^{2}-\frac{\left(\sum y\right)^{2}}{n}\right)}}
$$


dimana,

$\mathrm{r}=$ koefisien determinasi

$\mathrm{X}=$ Nilai dalam distribusi variabel $\mathrm{X}$

$\mathrm{Y}=$ Nilai dalam distribusi variabel $\mathrm{Y}$

Jika $r$ hitung $>$ r tabel, maka Ho di tolak Jika $r$ hitung $<\mathrm{r}$ tabel, maka Ho di terima dengan taraf nyata 0,05 . Harga $r$ dikonsultasikan dengan tabel interpretasi nilai $r$ seperti pada Tabel 1.

Tabel 1. Interpretasi nilai koefisien determinasi (r).

\begin{tabular}{cl}
\hline Interval koefisien $r$ & Tingkat hubungan \\
\hline $0,000-0,199$ & Sangat rendah \\
$0,200-0,399$ & Rendah \\
$0,400-0,599$ & Cukup \\
$0,600-0,799$ & Kuat \\
$0,800-1,000$ & Sangat kuat \\
\hline
\end{tabular}

\section{HASIL DAN PEMBAHASAN}

Penyiraman pada bibit tanaman teh klon GMB7 pada interval yang berbeda memberikan pengaruh nyata terhadap pertumbuhan jumlah daun, luas dan indeks luas daun, root shoot ratio, serta bobot kering tajuk. Komponen jumlah daun merupakan salah satu parameter penting dalam menentukan bibit siap salur. Bibit teh siap salur memiliki kriteria diantaranya sudah memasuki usia minimal delapan bulan, tinggi bibit minimal $30 \mathrm{~cm}$ dengan minimal 5 helai daun (PPTK, 2006). Hasil analisis statistik pada Tabel 2 menunjukkan bahwa bibit yang disiram dengan berbagai interval yang berbeda memiliki jumlah daun di atas syarat minimal siap salur, sedangkan bibit tanpa disiram memiliki jumlah daun di bawah syarat siap salur dan mengalami rerata kehilangan daun tertinggi.

Tabel 2. Pengaruh interval penyiraman terhadap tinggi tanaman (cm), diameter batang (mm), dan jumlah daun dan pengurangan jumlah daun bibit klon GMB-7 pada hari ke-57 setelah perlakuan.

\begin{tabular}{lcccc}
\hline \multicolumn{1}{c}{ Perlakuan interval penyiraman } & Tinggi & Diameter & Jumlah & Pengurangan \\
Tanaman $(\mathrm{cm})$ & Batang $(\mathrm{mm})$ & Daun & jumlah daun \\
\hline P0=Tanpa penyiraman & 28.85 & 3.65 & $3.75 \mathrm{a}$ & $-5.00 \mathrm{a}$ \\
P1=Tanpa penyiraman + Kitosan $2 \mathrm{ml} / 1$ & 24.34 & 3.56 & $9.63 \mathrm{~b}$ & $1.88 \mathrm{~b}$ \\
P2= 1 hari sekali & 22.08 & 3.35 & $8.75 \mathrm{~b}$ & $0.25 \mathrm{~b}$ \\
P3= 3 hari sekali & 26.99 & 4.00 & $10.63 \mathrm{~b}$ & $-0.50 \mathrm{~b}$ \\
P4= 5 hari sekali & 25.04 & 3.63 & $9.00 \mathrm{~b}$ & $0.00 \mathrm{~b}$ \\
P5= 7 hari sekali & 25.08 & 4.00 & $11.38 \mathrm{~b}$ & $2.13 \mathrm{~b}$ \\
P6= 9 hari sekali & 27.45 & 3.77 & $10.13 \mathrm{~b}$ & $-0.75 \mathrm{~b}$ \\
\hline
\end{tabular}

Keterangan: Angka yang diikuti huruf pada kolom yang sama menunjukkan berbeda nyata berdasarkan uji jarak berganda Duncan pada taraf kepercayaan 95\%.

Bibit yang pada kondisi cekaman air tanpa disiram mengalami kehilangan daun secara konsisten terus menurun hingga mencapai puncaknya di akhir pengamatan (Gambar 1). Bibit tanpa penyiraman yang diberi kitosan $2 \mathrm{~m} / \mathrm{l}$ melalui daun sebanyak dua kali dengan interval 30 hari memiliki jumlah daun yang tidak berbeda nyata dengan perlakuan penyiraman (Tabel 2) dan mampu mengurangi tingkat kehilangan daun hingga akhir pengamatan hari ke-57 (Gambar 1).

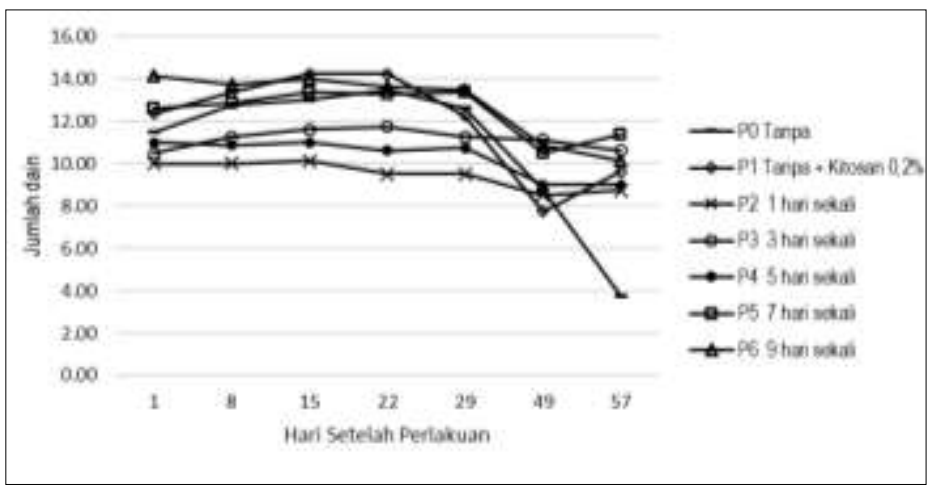

Gambar 1. Pengaruh interval penyiraman terhadap jumlah daun sampai hari ke-57 setelah perlakuan. 
Pengurangan jumlah daun pada kondisi cekaman memberikan pengaruh terhadap parameter luas daun dan indeks luas daun (ILD) namun tidak berpengaruh nyata terhadap berat daun khas (BDK)/ spesific leaf weight (SLW). Hasil analisis pada Tabel 3 menunjukkan bahwa luas daun pada bibit tanpa penyiraman jauh lebih rendah dibandingakan dengan penyiraman, sedangkan interval 7 hari memiliki luas daun tertinggi sejalan dengan indeks luas daun (Tabel 3). Aplikasi kitosan $2 \mathrm{~mL} . \mathrm{L}^{-1}$ pada bibit yang tidak disiram memiliki luas daun dan ILD yang tidak berbeda nyata dengan interval penyiraman setiap hari, 3, 5, dan 9 hari sekali (Tabel $3)$.

Tabel 3. Luas daun, Spesific leaf weight (SLW), dan indeks luas daun (ILD) bibit klon GMB-7 pada hari ke57 setelah perlakuan.

\begin{tabular}{lccc}
\hline \multicolumn{1}{c}{ Perlakuan interval penyiraman } & Luas & SLW $\left(\mathrm{g} \cdot \mathrm{cm}^{-2}\right)$ & ILD \\
\hline P0=Tanpa penyiraman & $63.39 \mathrm{a}$ & 98.17 & $1.27 \mathrm{a}$ \\
P1=Tanpa penyiraman + Kitosan 2 ${\mathrm{mL} . \mathrm{L}^{-1}}^{2}$ & $170.18 \mathrm{bc}$ & 116.88 & $3.42 \mathrm{bc}$ \\
P2= 1 hari sekali & $147.99 \mathrm{~b}$ & 125.72 & $2.97 \mathrm{~b}$ \\
P3= 3 hari sekali & $192.13 \mathrm{bc}$ & 103.43 & $3.86 \mathrm{bc}$ \\
P4= 5 hari sekali & $168.13 \mathrm{bc}$ & 97.54 & $3.38 \mathrm{bc}$ \\
P5= 7 hari sekali & $248.33 \mathrm{~d}$ & 97.40 & $4.99 \mathrm{~d}$ \\
P6= 9 hari sekali & $207.36 \mathrm{bc}$ & 111.42 & $4.17 \mathrm{bc}$ \\
\hline
\end{tabular}

Keterangan: Angka yang diikuti huruf pada kolom yang sana menunjukkan berbeda nyata berdasarkan uji jarak berganda Duncan pada taraf kepercayaan 95\%

Perlakuan interval penyiraman memberikan pengaruh nyata terhadap root shoot ratio (R/S). Hasil analisis statistika menunjukkan bahwa perbandingan $\mathrm{R} / \mathrm{S}$ pada bibit tanpa disiram lebih tinggi daripada bibit pada kondisi disiram (Tabel 4). Pertumbuhan bibit dapat dilihat dari indikator bobot kering (Paramita et al., 2014). bobot kering merupakan penimbunan hasil bersih asimilat sepanjang pertumbuhan tanaman (Gardner et al.,
1991). Interval penyiraman 7 hari sekali memiliki bobot kering tajuk yang tertinggi, sedangkan bibit teh tanpa penyiraman memiliki bobot kering tajuk terendah dibandingkan perlakuan interval penyiraman (Tabel 4). Aplikasi kitosan $2 \mathrm{ml} / 1$ pada bibit yang tidak disiram mampu mempertahankan bobot kering tajuk sehingga tidak berbeda nyata dengan interval penyiraman setiap hari, 3,5 , dan 9 hari sekali (Tabel 4).

Tabel 4. Root-shoot ratio, bobot kering tajuk, dan bobot kering akar, bibit klon GMB-7 pada hari ke -57 setelah perlakuan.

\begin{tabular}{lccc}
\hline \multicolumn{1}{c}{ Perlakuan interval penyiraman } & $R / S$ ratio & $\begin{array}{c}\text { Bobot kering } \\
\text { tajuk }(\mathrm{g})\end{array}$ & $\begin{array}{c}\text { Bobot kering } \\
\text { akar }(\mathrm{g})\end{array}$ \\
\hline P0=Tanpa penyiraman & $0.83 \mathrm{~b}$ & $1.46 \mathrm{a}$ & 0.99 \\
P1=Tanpa penyiraman + Kitosan $2 \mathrm{ml} / 1$ & $0.38 \mathrm{a}$ & $2.26 \mathrm{bc}$ & 0.85 \\
P2= 1 hari sekali & $0.45 \mathrm{a}$ & $1.88 \mathrm{ab}$ & 0.80 \\
P3= 3 hari sekali & $0.38 \mathrm{a}$ & $2.58 \mathrm{bcd}$ & 1.00 \\
P4= 5 hari sekali & $0.38 \mathrm{a}$ & $2.10 \mathrm{abc}$ & 0.79 \\
P5= 7 hari sekali & $0.36 \mathrm{a}$ & $3.03 \mathrm{~d}$ & 1.01 \\
P6= 9 hari sekali & $0.34 \mathrm{a}$ & $2.76 \mathrm{~cd}$ & 0.91 \\
\hline
\end{tabular}

Keterangan: Angka yang diikuti huruf pada kolom yang sama menunjukkan berbeda nyata berdasarkan uji jarak berganda Duncan pada taraf kepercayaan 95\%.

Kitosan menginduksi ketahanan terhadap menahan penurunan kandungan air nisbi pada cekaman kekeringan diantaranya melalui kondisi kekeringan (Zhang et al., 2018; mekanisme penutupan stomata, mengurangi Pichyangkura \& Chadchawan, 2015; Yang et al., kerusakan membran sela akibat peroksida lipid, 2009). Resistensi kekeringan yang diinduksi kitosan 
berkaitan erat dengan akumulasi metabolit untuk melindungi tanaman dari dampak cekaman, berkontribusi terhadap peningkatan penyesuaian osmotik, kapasitas antioksidan, persinyalan cekaman, dan produksi energi untuk pertahanan cekaman, sehingga mempertahankan homeostasis pada kondisi dehidrasi ( $\mathrm{Li}$ et al., 2017). Aplikasi kitosan pada bibit tanaman teh yang dikondisikan cekaman air, sampai dengan hari ke-57 dapat mencegah kehilangan daun (Tabel 2), menjaga luas dan indeks luas daun (Tabel 3), sehingga dapat menjaga bobot kering tajuk dan root shoot ratio dibandingkan dengan tanpa pemberian kitosan pada bibit teh dalam kondisi cekaman air.

Hubungan antara interval penyiraman dengan parameter jumlah daun (Gambar 2), luas daun (Gambar 3) dan R/S ratio (Gambar 4) memiliki pola polinomial dengan koefisien determinasi $\left(\mathrm{R}^{2}\right)$ masing-masing yang kuat yaitu $0,724,0,802$, dan 0,745 (Tabel 5). Berdasarkan Gambar 2 dan Gambar 3, dapat diamati bahwa bibit teh dapat mempertahankan pertumbuhan daunnya, baik itu jumlah maupun luas daun hingga titik optimalnya pada interval penyiraman 6-7 hari sekali (Tabel 5), setelah itu pertumbuhan daun mulai berkurang.

Tabel 5. Persamaan polinomial dan nilai optimum dari variabel respon jumlah daun, luas daun dan rootshoot ratio

\begin{tabular}{lllc}
\hline \multicolumn{1}{c}{ Variabel respon } & \multicolumn{1}{c}{ Model polinomial } & \multicolumn{1}{c}{$\mathrm{R}^{2}$} & Nilai optimum $(\partial \mathrm{f} / \partial \mathrm{x})$ \\
\hline Jumlah Daun & $\mathrm{y}=-0.1539 \mathrm{x}^{2}+1.901 \mathrm{x}+5.2481$ & $\mathrm{R}^{2}=0.723$ & 6.18 \\
Luas Daun & $\mathrm{y}=-2.7774 \mathrm{x}^{2}+39.154 \mathrm{x}+84.454$ & $\mathrm{R}^{2}=0.802$ & 7.05 \\
R/S Ratio & $\mathrm{y}=0.0099 \mathrm{x}^{2}-0.1259 \mathrm{x}+0.7082$ & $\mathrm{R}^{2}=0.745$ & 6.36 \\
\hline
\end{tabular}

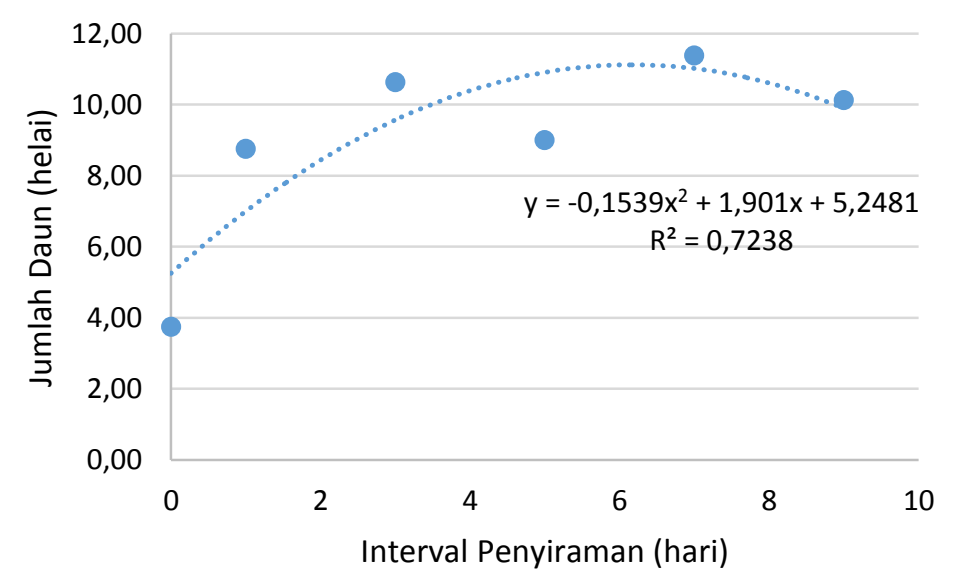

Gambar 2. Hubungan regresi polinomial antara jumlah daun (helai) dan interval penyiraman (hari).

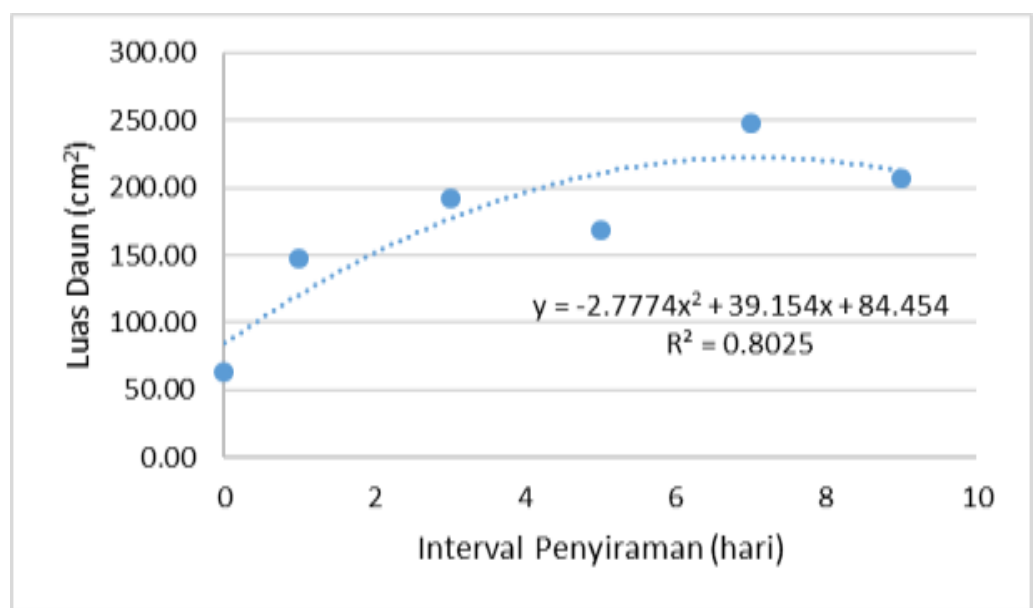

Gambar 3. Hubungan regresi polinomial antara luas daun $\left(\mathrm{cm}^{2}\right)$ dan interval penyiraman (hari) 
Interval penyiraman dan $\mathrm{R} / \mathrm{S}$ menunjukkan hubungan yang berlawanan (Gambar 4), dimana R/S semakin menurun seiring peningkatan interval penyiraman hingga mencapai titik optimal pada hari ke-enam (Tabel 5. Root shoot ratio (R/S) memiliki korelasi negatif yang nyata dengan bobot kering tajuk (BKT) dan pertumbuhan daun, BKT berkorelasi nyata positif dengan semua parameter pertumbuhan daun (Tabel 6), sementara interval penyiraman tidak berpengaruh terhadap bobot kering akar (Tabel 4). Penurunan R/S disebabkan karena pertumbuhan tajuk yang dapat dipertahankan hingga interval penyiraman enam hari sekali, setelah itu seiring dengan penurunan pertumbuhan tajuk R/S semakin meningkat.

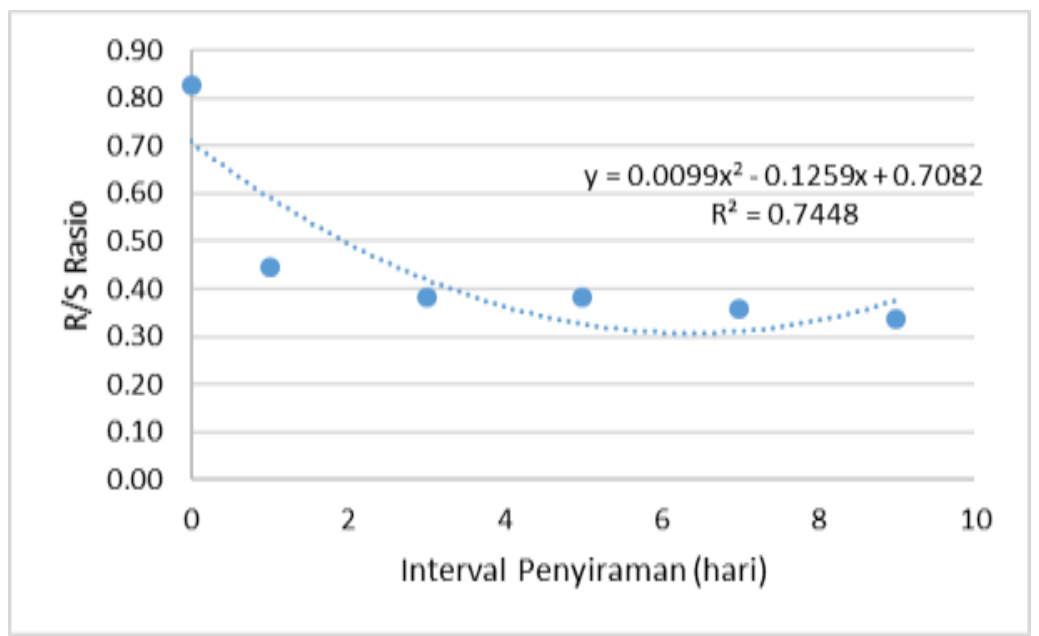

Gambar 4. Hubungan regresi polinomial antara root-shoot ratio $(\mathrm{R} / \mathrm{S})$ dan interval penyiraman (hari)

Tabel 6. Korelasi pearson hubungan antara prameter pertumbuhan daun dengan biomassa tajuk.

\begin{tabular}{lrrrrr}
\hline & BKT & R/S & LD & ILD & JD \\
\hline BKT & 1 & & & & \\
R/S & $-0.666^{* *}$ & 1 & & & \\
LD & $0.933^{*}$ & $-0.726^{*}$ & 1 & & \\
ILD & $0.933^{* *}$ & $-0.726^{*}$ & $1.000^{* *}$ & 1 & \\
JD & $0.822^{* *}$ & $-0.787^{* *}$ & $0.903^{* *}$ & $0.903^{* *}$ & 1 \\
\hline
\end{tabular}

Keterangan: BKT: berat kering tajuk (g); R/S: root-shoot ratio; LD: luas daun (cm2); ILD: indeks luas daun; JD: jumlah daun. ${ }^{* *}$ )beda nyata pada taraf kepercayaan $99 \%$.

Morfologi dan struktur anatomi daun merupakan parameter yang dengan mudah digunakan untuk memperkirakan tingkat kerusakan tanaman akibat kondisi cekaman kekeringan pada tanaman teh (Qian et al., 2018). Perlakuan interval penyiraman untuk memberikan kondisi cekaman kekeringan berdampak terhadap pengurangan jumlah (Tabel 2) dan luas daun (Tabel 3), namun tidak memberikan pengaruh terhadap SLW (Tabel 3). Spesific leaf weight (SLW) merupakan bobot kering daun tiap satuan luas daun (Xi \& Yong, 2016), dan memiliki korelasi yang kuat dengan ketebalan daun (Jumrani et al., 2017).

Jumlah dan ukuran daun lebih dipengaruhi oleh genotipe dan lingkungan tempat tumbuhnya, jumlah daun yang banyak dan daun yang luas mampu mendukung tanaman membentuk fotosintat yang nantinya didistribusikan untuk pembentukan organ-organ vegetatif lainnya (Gardner et al., 1991). Daun adalah parameter yang terkait erat dengan proses fotosintesis sehingga semakin banyak jumlah daun semakin banyak pati yang dihasilkan untuk pertumbuhan dan perkembangan stek (Dalimoenthe, 2014).

Pada kondisi cekaman kekeringan, kandungan air dalam daun secara signifikan menurun setelah hari ke tujuh dan berkorelasi dengan penurunan bobot kering daun (Upadhyaya \& Panda, 2013). Interval penyiraman memiliki pola hubungan polinomial, dimana parameter jumlah dan luas daun meningkat seiring peningkatan interval hingga mencapai titik optimalnya pada hari ke enam (Tabel 5) setelah itu menurun pada kondisi interval yang terus meningkat. Fotosintesis merupakan 
metabolisme utama yang menentukan produksi tanaman, dan secara langsung dipengaruhi oleh pasokan air (Pieters \& Souki, 2005).

Air adalah faktor lingkungan inti untuk pertumbuhan dan perkembangan tanaman, baik kelebihan maupun kekurangan air dapat menyebabkan kondisi cekaman. Kondisi kelebihan air, mengacu pada kelembaban tanah yang melebihi kapasitas lapangan dan berakibat pada berkurangnya pasokan oksigen ke akar, dan fungsi-fungsi akar kritis, termasuk respirasi dan penyerapan nutrisi (Qian et al., 2018). Terdapat hubungan yang sangat erat pada penurunan laju fotosintesis seiring peningkatan kelebihan pasokan air (Deka et al., 2011). Penurunan laju fotosintesis pada kondisi kelebihan pasokan air berhubungan dengan penurunan konduktivitas stomata, bahkan pada kondisi laju transpirasi yang rendah (Deka et al., 2011).

Root shoot ratio (R/S) digunakan untuk membantu menilai kesehatan tanaman secara keseluruhan dan mengevaluasi potensi tanaman untuk menghindar dalam menghadapi cekaman (Riaz et al., 2013). Sejalan dengan parameter daun, interval penyiraman memberikan dampak terhadap penurunan R/S (Tabel 4) pada interval penyiraman diatas enam hari (Gambar 4). Penelitian yang dilakukan oleh Chen et al., (2010) menunjukkan bahwa interval penyiraman menyebabkan penurunan potensial air yang berhubungan erat dengan pengurangan biomassa pucuk daun teh, dimana bobot kering masih meningkat pada interval penyiraman 5 hari dan mulai menurun pada interval penyiraman di atas 10 hari. Bibit teh pada kondisi cekaman kekeringan berpengaruh nyata terhadap bobot kering tajuk (BKT), namun tidak berpengaruh nyata terhadap bobot kering akar (Tabel 4). Root shoot ratio $(\mathrm{R} / \mathrm{S})$ memiliki korelasi negatif yang nyata dengan BKT $\left(\mathrm{R}^{2}=-0.666\right)$, sementara BKT memiliki korelasi positif nyata yang sangat kuat dengan JD $\left(\mathrm{R}^{2}=0.822\right)$, LD dan ILD $\left(\mathrm{R}^{2}=0.933\right)$. Tajuk adalah organ penting dan sangat kritis untuk pertumbuhan dan perkambangan akar (Dalimoenthe, 1996).

Alokasi bobot kering pada tanaman terkait dengan rasio total bobot kering tajuk dan akar sebagai dua organ penumpukan fotosintat utama dalam tanaman (Cheruiyot et al., 2010). Pada kondisi cekaman air, tanaman pada umumnya diketahui berinvestasi lebih banyak bahan kering di akar daripada pucuk dan secara bertahap menggeser alokasi bahan kering untuk pucuk saat kadar air tanah menjadi pembatas (Munns \& Cramer, 1996).

\section{SIMPULAN}

Interval penyiraman berpengaruh nyata terhadap root shoot ratio, berat kering tajuk, jumlah dan luas daun bibit teh klon GMB 7. Perlakuan kitosan menunjukkan nilai jumlah daun, root shoot ratio dan pengurangan daun yang lebih tinggi dibanding tanpa penyiraman. Penurunan root shoot ratio, berat kering tajuk, jumlah dan luas daun mulai terjadi setelah mencapai titik optimumnya pada interval penyiraman 6 hari sekali. Oleh karena itu, penyiraman 6 hari sekali merupakan interval ideal untuk mempertahankan pertumbuhan bibit teh klon GMB 7 pada kondisi cekaman kekeringan saat proses adaptasi.

\section{UCAPAN TERIMA KASIH}

Penulis mengucapkan terima kasih kepada jajaran manajemen kebun Pusat Penelitian Teh dan Kina, teknisi lapangan dan pihak-pihak yang ikut berkontribusi terhadap teknis pelaksanaan penelitian ini.

\section{DAFTAR PUSTAKA}

Abdel-Mawgoud, AMR, AS Tantawy, MA El-Nemr, and YN Sassine. 2010. Growth and yield responses of strawberry plants to chitosan application. European Journal of Scientific Research. 39(1), pp.170-177. https://www.researchgate.net/publication/287 681481

Abu-Muriefah, SS. 2013. Effect of chitosan on common bean (Phaseolus vulgaris L.) plants grown under water stress conditions. International Research Journal of Agricultural Science and Soil Science. 3(6): 192-199. http://www.interesjournals.org/IRJAS.

Badan Pusat Statistik [BPS]. 2018. Statistik Teh Indonesia 2018. Jakarta: Badan Pusat Statistik Republik. Indonesia.

Chen, XH, CG Zhuang, YF He, L Wang, GQ Han, C Chen, and HQ He. 2010. Photosynthesis, yield, and chemical composition of Tieguanyin tea plants (Camellia sinensis (L.) O. Kuntze) in response to irrigation 
treatments. Agricultural Water Management, 97(3):419-425.

Cheruiyot, EK, LM Mumera, WK Ngetich, A Hassanali, and FN Wachira. 2010. High fertilizer rate increase susceptibility of tea to water stress. Journal of Plant Nutrition. 33:115-129.

Choubey M, R Kumar, A Chakraborty, JS Bisen, AK Singh, and M Singh. 2013. Performance of tea clones in the nursery through vegetative propagation in Darjeeling. International Journal of Science Research Publication. 3(11):1-4.

Dalimoenthe SL. 1996. Sekam padi sebagai media pembibitan setek teh. Warta Teh dan Kina. 7 (4):115-122.

Dalimoenthe SL. 2014. Effects of organic medium on growth and root formation of Cinchona ledgeriana planting material at early stage of nursery. Indonesia Journal of Tea and Cinchona Research. 17(2):57-7

Dalimoenthe, SI, dan Y Rachmiati. 2009. Dampak perubahan iklim terhadap kadar air tanah di perkebunan teh.Jurnal Penelitian Teh dan Kina. 12(3): 59-66.

Deka, DK, D Borah, T Lahon, U Baruah, AK Handique, and TS Barman. 2011. Selection of waterlogging tolerant tea (Camellia sinensis L.) genotypes. Journal of Plantation Crops. 39 (1): 203-209.

Farouk, S, and AR Amany. 2012. Improving growth and yield of cowpea by foliar application of chitosan under water stress. Egyptian Journal of Biology 14: 14-26. http://dx.doi.org/10.4314/ejb.v14i1.2

Gardner F, R Pearce, and R Mitchell. 1991. Physiology of Crop Plants (Fisiologi Tanaman Budidaya, alih bahasa: S. Herawati). Universitas Indonesia: Jakarta.

Hajra, NG. 2001. Tea Cultivation Comprehensive Treatise. International Book Distribiting Company, India. $1^{\text {st }}$ Ed. Page:92

International Tea Committee [ITC]. 2019. Annual Bulletin of Statistics: London.

Jumrani, K, VS Bhatia, and GP Pandey. 2017. Impact of elevated temperatures on specific leaf weight, stomatal density, photosynthesis and chlorophyll fluorescence in soybean. Photosynthesis Research, 131(3):333-350.

Kartawijaya, WS. 1992. Evaluasi Pengaruh Kemarau Panjang Tahun 1991 terhadap Produksi di
Beberapa Perkebunan Teh. Warta Teh dan Kina. 3 (3-4): 55-71.

Li, Z, Y Zhang, X Zhang, E Merewitz, Y Peng, X Ma, and Y Yan. 2017. Metabolic pathways regulated by chitosan contributing to drought resistance in white clover. Journal of Proteome Research. 16(8): 3039-3052.

Malerba, M, and R Cerana. 2016. Review: Chitosan Effects on Plant Systems. International Journal of Molecular Science. 17: 996. doi:10.3390/ijms17070996

Maritim, TK, SM Kamunya, P Mireji, C Mwendia, RC Muoki, EK Cheruiyot, and FN Wachira. 2015. Physiological and biochemical response of tea [Camellia sinensis (L.) O. Kuntze] to water-deficit stress. The Journal of Horticultural Science and Biotechnology. 90(4):395-400.

Munns, R, and GR Cramer. 1996. Is coordination of leaf and root growth mediated by abscisic acid? Opinion. Plant and Soil 185: 33-49.

Osakabe, Y, K Osakabe, K Shinozaki, and LSP Tran. 2014. Response of plants to water stress. Frontiers in Plant Science. 5: 86.

Paramita, IGM, D Indradewa, and S Waluyo. 2014. Pertumbuhan bibit tujuh klon teh (Camellia sinensis (L.) Kuntze) PGL dengan pemberian bahan mengandung hormon tumbuh alami. Vegetalika. 3(2):1-12.

Parwata, IGM, D Indradewa, P Yudono, and BD Kertonegoro. 2010. Pengelompokan genotipe jarak pagar berdasarkan ketahanannya terhadap kekeringan pada fase pembibitan di lahan pasir pantai. Jurnal Agronomi Indonesia. 38(2):156 - 162.

Pichyangkura, R, and S Chadchawan. 2015. Biostimulant activity of chitosan in horticulture. Scientia Horticulturae. 196:4965.

Pieters, AJ, and SE Souki. 2005. Effects of drought during grain filling on PS II activity in rice. Journal of Plant Physiology. 162:903-911.

Pusat Penelitian Teh dan Kina [PPTK]. 2006. Petunjuk Kultur Teknis Tanaman Teh edisi ketiga. Santoso, J, R Supriatini, W Widayat, ME Johan, DJ Rayati, dan A Dharmadi (red). Gambung, Bandung: Pusat Penelitian Teh dan Kina.

Qian, W, Hu J, Zhang X, Zhao L, Wang Y, \& Ding Z. 2018. Response of tea plants to drought stress Pp. 63-81 in Stress Physiology of Tea in the Face of Climate Change. Springer, Singapore. 
Riaz, A, A Younis, AR Taji, A Karim, U Tariq, S Munir and S Riaz. 2013. Effect of drought stress on growth and flowering of marigold (Tagetes erecta 1.). Pakistan Journal of Botani. 45(S1): 123-131. https:/www.researchgate.net/publication/259 484411

Santoso, J, dan R Suprihartini. 2006. Perspektif Bisnis Komoditi Teh. Warta Pusat Penelitian Teh dan Kina. 17(1-3): 239-249

Santoso, J, dan R Suprihartini. 2007. Kebijakan yang perlu diperjuangkan untuk revitalisasi agribisnis teh nasional. Warta Pusat Penelitian Teh dan Kina. 18(1-3): 1-18

Sasmita, ER, dan H Darban. 2016. Penerapan kitosan terhadap pertumbuhan vegetatif tanaman kemiri sunan. Agrivet. 22 (2):27-36.

Setiawan, Tohari, dan D Shiddieq. 2013. Pengaruh cekaman kurang air terhadap beberapa karakter fisiologis tanaman nilam (Pogostemon cablin Benth). Jurnal Penelitian Tanaman Industri. 19 (3): 108-116.

Suharti, M, dan D Gusmalawati. 2017. Struktur anatomi akar, batang dan daun gaharu (Aquilaria malaccensis Lamk.) yang mengalami cekaman kekeringan. Jurnal Protobiont. 6 (2): 38 - 44.

Sukasman. 1992. Pengaruh kemarau panjang terhadap tanaman teh dan usaha penanggulangan secara agronomi. Warta Teh dan Kina. 3 (3/4).

Upadhyaya, H, and SK Panda. 2013. Abiotic stress responses in tea [Camellia sinensis L (O) Kuntze]: an overview. Reviews in Agricultural Science. 1:1-10.

Wulansari, R, Y Rachmiati, dan E Rezamela. 2017. Pengaruh aplikasi pupuk daun mineral dan orgaik cair terhadap perningkatan pertumbuhan benih teh siap salur. Creative Research Journal. 2(02):135-146.

Xi, LIU, and LI Yong. 2016. Varietal difference in the correlation between leaf nitrogen content and photosynthesis in rice (Oryza sativa L.) plants is related to specific leaf weight. Journal of integrative agriculture. 15(9):20022011.

Yang, F, J Hu, J Li, X Wu, and Y Qian. 2009. Chitosan enhances leaf membrane stability and antioxidant enzyme activities in apple seedlings under drought stress. Plant Growth Regulation. 58(2):131-136. 10.1007/s10725-009-9361-4.

Zhang, Y, Z Li, YP Li, XQ Zhang, X Ma, LK Huang, and Y Peng. 2018. Chitosan and spermine enhance drought resistance in white clover, associated with changes in endogenous phytohormones and polyamines, and antioxidant metabolism. Functional Plant Biology. 45(12):1205-1222. 